\title{
Black flies that suck blood from Japanese deer (Cervus nippon) and filarial infection in the flies
}

\author{
Nobuo Yamashita ${ }^{1)}$, Chiharu Aoki ${ }^{2)}$ and Hiroyuki TAKaokA ${ }^{2)}$ \\ 1) Department of Animal Husbandry, Tohoku National Agricultural Experiment Station, \\ Akahira, Morioka, Iwate, 020-0198 Japan \\ 2) Department of Infectious Disease Control, School of Medicine, Oita Medical University, \\ Hasama-machi, Oita, 879-5593 Japan
}

(Received: 27 July 1999; Accepted: 17 February 2000)

Key words: black fly, filaria, Iwate Prefecture, Japanese deer, vector

\begin{abstract}
In a study of whether black flies transmit pathogens from deer to livestock, black flies were collected with a light trap at a deer shed in Morioka, Iwate Prefecture, Japan, and examined for natural infection with filariae. A total of 970 black flies belonging to the following five species were captured: Simulium bidentatum, $S$. iwatense, S. aokii, S. nikkoense, and S. daisense. All but S. daisense sucked blood from deer. S. bidentatum, S. iwatense, and S. nikkoense had sucked blood from both cattle and deer. S. bidentatum was naturally infected with first-stage filarial larvae in the pectoral muscle. The black flies may carry pathogens between deer and cattle.
\end{abstract}

\section{INTRODUCTION}

Recently, the number of Japanese deer (Cervus nippon) has been increasing in many regions, causing severe crop damage. On the other hand, deer ranches have been opened to promote industry in villages. These deer ranches are often close to cattle pastures, and encounters among deer, livestock, and people are becoming more common. Many Japanese deer possess a high level of antibodies to livestock-disease pathogens, such as blue tongue virus and Akabane virus, and deer may spread disease to livestock (Imada et al., 1996).

Bloodsucking insects such as black flies can transmit pathogens (Anderson et al., 1961; Kolstrup, 1975; Schulz-Key and Wenk, 1981; Takaoka et al., 1989, 1992; Takaoka, 1999), but there have been few reports on black flies that sucked blood from deer (Schulz-Key and Wenk, 1981; Sasaki et al., 1986, 1988).

The purpose of this research was to clar- ify the possibility that black flies transmit pathogens of deer to livestock. Therefore, we surveyed the species of black flies that may suck blood from deer and examined the flies for natural infection with filariae.

The results indicated the possibility of black flies to carry pathogens between deer and cattle.

\section{Materials And Methods}

Black flies were collected at a deer shed in an animal-breeding facility of Tohoku National Agricultural Experiment Station in Morioka, Iwate, Japan, from June 1 to November 1 or 30 in 1995 and 1996, respectively. The shed stands in grassland with deer and sheep paddocks. A cattle paddock was about $100 \mathrm{~m}$ away, and some ten adult cattle were kept there. Woods and a small stream were nearby.

Three adult deer were being kept in the deer shed adjoining a sheep shed in the facility. About 30 adult sheep were always kept in the sheep shed. The deer shed had a room for feeding and resting (length $3 \mathrm{~m}$, 
width $4 \mathrm{~m}$, height, $3 \mathrm{~m}$ ) and a paddock with a concrete floor (length $3 \mathrm{~m}$, width 10 $\mathrm{m})$. The deer and insects, such as black flies and mosquitoes, could freely pass through the opening (width $1 \mathrm{~m}$, height $1.2 \mathrm{~m}$ ) between the room and the paddock. There was a window covered with a 1-inch wire mesh on the north wall of the deer shed facing the grassland.

A light trap with a black light bulb (Toshiba light trap FLM-601G, $20 \mathrm{~W}$ ) was suspended at a height of $2 \mathrm{~m}$ in the center of the feeding room. The light trap was left on continuously, and the bag for collecting insects was changed every morning during the survey. The sampling of each time was carried out over two days in this way. All of the black flies that were collected in the morning of the 2nd day were recorded as the individuals that had been captured on the 1st day, for the sake of convenience.

The flies collected were preserved in a freezer at $-30^{\circ} \mathrm{C}$ until the capture of the flies ended in November. The head, thorax, and genital segment of the flies were sent to Oita Medical University. After the species of the flies were identified (Bentinck, 1955), these specimens were dissected in a $5 \%$ Giemsa solution on a glass slide under a dissecting microscope and examined for filarial larvae (Takaoka et al., 1992). In Morioka, blood in the abdomens of the engorged flies collected in 1995 and 1996 was analyzed for its source by the direct enzyme-linked immunosorbent assay (ELISA). In brief, the abdomens of the frozen black flies were put into phosphate-buffered saline (PBS) and crushed to release any blood in the middle gut. The emulsion obtained was poured into plates for ELISA as the antigen. The antigen was adsorbed onto the wells of the plates and the plates were incubated at $4^{\circ} \mathrm{C}$ overnight. Thereafter, chicken serum was added as the coating buffer, and goat anti-bovine, goat anticervine, or goat anti-ovine serum was poured into the wells. Horseradish peroxidase conjugated with rabbit anti-goat serum was put into the wells, and the plates were incubated at $37^{\circ} \mathrm{C}$ for two hours. These sera and the peroxidase were commercial products of ICN Pharmaceuticals, Inc. (Costa Mesa, CA, U.S.A.). The emulsion in the wells was colored with a substrate solution (a mixture of $O$ phenylene diamine, citric acid- $\mathrm{Na}_{2} \mathrm{HPO}_{4}$ buffer, and $\mathrm{H}_{2} \mathrm{O}_{2}$ ), and the reaction was stopped by the addition of $4-\mathrm{N}$ sulfuric acid. The absorbance was measured by a microplate reader. PBS containing 0.5\% Tween 20 was used as a washing buffer after each treatment.

\section{Results}

\section{Species of black flies}

The species of captured black flies were the same in 1995 and 1996; Simulium bidentatum, S. iwatense, S. aokii, S. nikkoense, and $S$. daisense (Table 1). In both years, $S$. bidentatum, S. iwatense, and S. aokii were caught more abundantly than $S$. nikkoense or S. daisense. Simulium bidentatum, $S$. iwatense, and S. aokii were abundant in autumn and only $S$. nikkoense was abundant in midsummer. Only one S. daisense individual was captured, in October of each year.

\section{Source of ingested blood}

Of the 970 individuals captured, there were 100 flies engorged with blood (Table 1). Engorged individuals of S. bidentatum and $S$. iwatense were caught only in autumn, and their rates of engorged individuals were 8.1\% (31/383), 9.9\% (29/ 292), respectively. In contrast, engorged individuals of $S$. nikkoense were captured only in midsummer and the rate was $81.8 \%(18 / 22)$. Those of $S$. aokii were captured in summer and autumn and the rate was $8.1 \%(22 / 271)$. In 81 of the engorged flies, the source of the blood ingested was examined by ELISA, and blood sources of 20 flies were identified (Table $2)$. Seventeen flies belonging to four species, S. bidentatum, S. iwatense, S. aokii, and $S$. nikkoense, had sucked blood from 
Table 1. Number of black flies collected with a light trap at a deer shed in Morioka, Iwate, Japan, in 1995 and 1996.

1995

\begin{tabular}{|c|c|c|c|c|c|c|}
\hline Species & June & July & August & September & October & Total \\
\hline S. bidentatum & 0 & 0 & 0 & 3 & $362 *(31)$ & $365(31)$ \\
\hline S. iwatense & 4 & 0 & 0 & 4 & 117 (15) & 125 (15) \\
\hline S. aokii & 6 & $2(2)$ & 0 & 1 & 177 (15) & $186(17)$ \\
\hline S. nikkoense & 1 & $8(8)$ & $11(10)$ & 0 & 1 & $21(18)$ \\
\hline S. daisense & 0 & 0 & 0 & 0 & 1 & 1 \\
\hline Total & 11 & $10(10)$ & $11(10)$ & 8 & $658(61)$ & $698(81)$ \\
\hline
\end{tabular}

1996

\begin{tabular}{lccccccc}
\hline \hline \multicolumn{1}{c}{ Species } & June & July & August & September & October & November & Total \\
\hline S. bidentatum & 2 & 0 & 0 & 0 & 8 & 8 & 18 \\
S. iwatense & 0 & 1 & 1 & 0 & $128(13)$ & $37(1)$ & $167(14)$ \\
S. aokii & 0 & 0 & 0 & 0 & $27(2)$ & $58(3)$ & $85(5)$ \\
S. nikkoense & 0 & 0 & 0 & 0 & 1 & 0 & 1 \\
S. daisense & 0 & 0 & 0 & 0 & 1 & 0 & 1 \\
\hline \multicolumn{1}{c}{ Total } & 2 & 1 & 1 & 0 & $165(15)$ & $103(4)$ & $272(19)$ \\
\hline
\end{tabular}

* Four black flies infected with filariae are included.

Numbers of engorged individuals are in parentheses.

Table 2. Source of blood ingested by black flies collected with a light trap at a deer shed in Morioka, Iwate, Japan, in 1995 and 1996.

\begin{tabular}{|c|c|c|c|c|c|c|}
\hline \multirow{2}{*}{ Species } & \multirow{2}{*}{$\begin{array}{c}\text { Number of } \\
\text { individuals } \\
\text { collected }\end{array}$} & \multirow{2}{*}{$\begin{array}{c}\text { Number of } \\
\text { engorged } \\
\text { individuals }\end{array}$} & \multicolumn{3}{|c|}{ Blood source identified as } & \multirow{2}{*}{$\begin{array}{l}\text { Blood source } \\
\text { not identified }\end{array}$} \\
\hline & & & Deer & Cattle & Sheep & \\
\hline S. bidentatum & 383 & $31(27)$ & 2 & 1 & 0 & 24 \\
\hline S. iwatense & 292 & 29 (18) & 1 & 1 & 0 & 16 \\
\hline S. aokii & 271 & $22(18)$ & 4 & 0 & 0 & 14 \\
\hline S. nikkoense & 22 & $18(18)$ & 10 & 1 & 0 & 7 \\
\hline S. daisense & 2 & $0(0)$ & no test & no test & no test & no test \\
\hline Total & 970 & $100(81)$ & 17 & 3 & 0 & 61 \\
\hline
\end{tabular}

Numbers of individuals examined are in parentheses.

deer and all but S. aokii sucked blood from cattle as well. No black flies had sucked blood from sheep.

\section{Filarial infection}

Four black flies infected with filariae were collected on October 1-2, 19-20, 2526 , and 28-29 in 1995. No black flies infected with filariae were collected in 1996. All filariae found were first-stage larvae, and they were detected only in the pectoral muscle of $S$. bidentatum. The caudal portion of the filaliae curled (Fig. 1). The mean body length was $116.8 \mu \mathrm{m}$ (range, 80.1 to $133.1 \mu \mathrm{m}$ ), and the mean maximum body width was $10.5 \mu \mathrm{m}$ (range, 6.0 to $14.3 \mu \mathrm{m}$ ) in nine individuals.

\section{Discussion}

Our results showed that $S$. bidentatum, $S$. iwatense, $S$. aokii, and $S$. nikkoense sucked blood from deer and that $S$. bidentatum was naturally infected with first- 


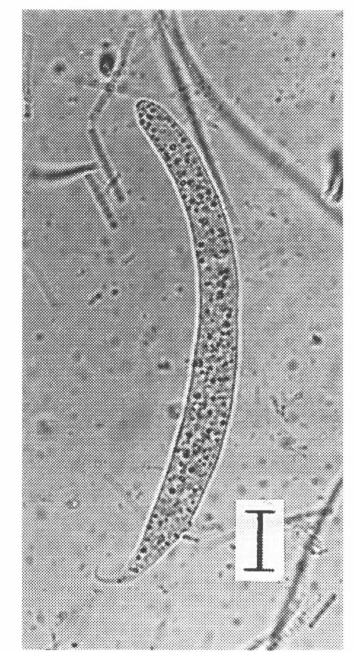

Fig. 1. First-stage larva of a filaria found in the thorax of $S$. bidentatum collected with a light trap at a deer shed in Morioka, Iwate, Japan.

Scale bar indicates $10 \mu \mathrm{m}$.

stage filarial larvae in the pectoral muscle.

Sasaki et al. $(1986,1988)$ confirmed with the use of ELISA that S. japonicum, Twinnia canivora, Distosimulium daisetsense, and Cnetha uchidai sucked blood from deer in Hokkaido. We confirmed four new species that sucked blood from deer. Our result showed that $S$. bidentatum, S. iwatense, and S. nikkoense had sucked blood from cattle as well. Deer have pathogens in common with cattle (Imada et al., 1996). These black flies might carry pathogens between deer and cattle.

Many kinds of black flies carry filariae (Takaoka, 1990, 1994; Takaoka et al., 1978, 1989, 1992). In our survey, uninfectivestage larvae of filariae were detected in the pectoral muscles of S. bidentatum collected in October 1995. This is the first report of natural infection with filarial larvae in a population of black flies that probably sucked blood from Japanese deer, furthermore, this is the first report of such natural infection of S. bidentatum in Iwate Prefecture. A previous survey at Shizukuishi-machi, a town near Morioka City, showed that S. iwatense, S. aokii, S. nikkoense, and $S$. daisense were infected with Onchocerca larvae (Takaoka et al.,
1992). Therefore, with the addition of $S$. bidentatum, a total of five kinds of black fly in the vicinity of Morioka may have been infected with filarial larvae.

As to whether S. bidentatum becomes a vector of this filaria, it is necessary to confirm whether filariae can grow to the infective-stage in the body of the black fly before the bloodsucking activity of the black fly stops. S. bidentatum are common species in Honshu and Kyushu areas (Takaoka, 1994; Takaoka et al., 1989, 1992; Shogaki et al., 1956), and more detailed work on them in the epidemiology of filariae is requred.

\section{ACKnowledgments}

We thank Mr. Yasuo Omori and Mr. Hisashi Tamura of Management Section Two at the Tohoku National Agricultural Experiment Station for installation and maintenance of the light trap.

\section{REFERENCES}

Anderson, J., V. Lee, S. Vadllamudi, R. Hanson and G. R. Deforiart (1961) Isolation of eastern encephalitis virus from Diptera in Wisconsin. Mosq. News, 21: 244-248.

[Bentinck, W.] (1955) The Black Flies of Japan and Korea (Diptera; Simuliidae), 23 pp. 406 Med. Gen. Lab., U. S. Army, Tokyo.

Imada, T., T. Tuboi, N. Takahashi, T. Hamaoka, M. Haritani, T. Miyamoto and H. Murata (1996) Serological survey of 8 bovine viral pathogens in sika deer (Cervus nippon) of northern Japan. Jpn. J. Zoo Wildlife Med., 1: 42-44.

Kolstrup, N. (1975) Onchocerca gutturosa in Danish cattle: prevalence, geographic distribution and host-vector relationship. Acta Vet. Scand., 16: 1-13.

Sasaki, H., Y. Nishijima and H. Ono (1986) Note on the blood source of black flies (Diptera: Simuliidae) collected at the Onnebetsu-dake area. Jpn. J. Saint. Zool., 37: 41-45.

Sasaki, H., Y. Nishijima and H. Ono (1988) Blood source of two major Simulium species in Hokkaido, Japan (Diptera: Simuliidae) collected at the Onnebetsu-dake area. Jpn. J. Saint. Zool., 39: 87-90.

Schulz-Key, H. and P. Wenk (1981) The transmission 
of Onchocerca tarsicola (Filarioidea: Onchocercidae) by Odagmia ornata and Prosimulium nigripes (Diptera: Simuliidae). J. Helminthol., 55: 161-166.

Shogaki, Y. and Y. Yoshida (1956) Studies on black flies of Yase district in Kyoto-City and its control. I. Notes on the diurnal rhythm of biting activity of Simulium (Gnus) nacojapi SMART (Simuliidae, Diptera). Jpn. J. Sanit. Zool., 7: 38-42 (in Japanese with English Summary).

Takaoka, H. (1990) Development of microfilariae of two bovine Onchocerca species in blackflies in Japan. Jpn. J. Trop. Med. Hyg., 18: 183-188.

Takaoka, H. (1994) Natural vectors of three bovine Onchocerca species (Nematoda: Onchocercidae) and their seasonal transmission by three black fly species (Diptera: Simuliidae) in central Kyushu, Japan. J. Med. Entomol., 31: 404-416.

Takaoka, H. (1999) Review on zoonotic Onchocerca species and their insect vectors in Japan. Med. Entomol. Zool., 50: 1-8 (in Japanese with English abstract).

Takaoka, H., C. Aoki and H. Hayakawa (1992) Natural infections of blackflies with larvae of zoonotic Onchocerca spp. in northeast Japan. Jpn. J. Trop. Med. Hyg., 20: 1-9.

Takaoka, H., C. Baba and O. Bain. (1989) Natural infections of Simulium bidentatum (Diptera: Simuliidae) with larvae of Onchocerca spp. in relation to a human zoonotic onchocerciasis in Oita, Japan. Jpn. J. Trop. Med. Hyg., 17: 279-284.

Takaoka, H., S. Noda and S. Yamamoto. (1978) Light trap catches of blackflies in southern part of Kyushu, Japan, Jpn. J. Sanit. Zool., 29: 107-115 (in Japanese with English Summary).

$$
\begin{gathered}
\text { 摘 要 } \\
\text { ニホンジカから吸血するブユ相と } \\
\text { フィラリア感染 }
\end{gathered}
$$

山下伸夫1) 青木千春 ${ }^{2)}$ 高岡宏行 ${ }^{2)}$

1) 東北農業試験場畜産部家畜虫害研究室

（干020-1234 岩手県盛岡市下厨川赤平 4)

2) 大分医科大学医学部感染予防医学講座

(干879-55 大分県大分郡挟間町医大ヶ丘 1-1)

ニホンジカを加害するブユの種類相とブユの病原媒介 能を明らかにするため, 1995 年と 1996 年に岩手県盛 岡市東北農試場内の二ホンジカを飼育しているシカ舎で ライトトラップを用いてシカから吸血するブュを捕獲 し, そのフィラリア感染状況を調查した. Simulium bidentatum, S. iwatense, S. aokii, S. nikkoense, S. daisense の 5 種類, 計 970 個体のブユが捕獲され, これらのうち S. daisense を除く 4 種はシカから吸血した. S. bidentatum, S. iwatense, S. nikkoense はシカと牛から吸血し た. S. bidentatum の胸筋でフィラリア幼虫が確認され た. ブユがシカとウシの間で病原を媒介する可能性があ る. 